\title{
Multi-Attribute Decision Making Using Simple Additive Weighting and Weighted Product in Food Choice
}

\author{
Adriyendi \\ Informatic Dept., STAIN Batusangkar \& UPI YPTK Padang, Indonesia \\ Email: suratadriyendi@gmail.com
}

\begin{abstract}
This paper provide an overview of the analysis and implementation Multi-Attribute Decision Making (MADM) for food selection or food choice. Food choice aim to find the solution on lack of food. Food choice can be doing with diversification. Food diversification aims to find best choice of food alternatives. Food alternative is rice, corn, cassava, potato, sago, sorghum, wheat, and analog rice. The method used is Simple Additive Weighting (SAW) and Weighted Product (WP). The use of this method is expected to help and provide the best decision in food choice. Alternative on MADM as data training, alternative on SAW method and alternative on WP method as data testing. Experimental result on SAW method, best alternative (highest value) is wheat with value 0.8833 . On WP method, best alternative (highest value) is wheat with value 0.1563 . On SAW method and WP method, decision is the same with wheat as best alternative in MADM on food choice.
\end{abstract}

Index Terms - Alternative, attribute, simple additive weighting, weighted product, food choice.

\section{INTRODUCTION}

Rice is major source of staple food of more than two third of population. Rice is major source of staple food in Indonesia [1]. Types of rice including white rice, brown rice, glutinous rice, basmati rice, brown rice, black rice and jasmine rice. For it, rice consumption must be improved [2]. Rice consumption is tended to increase, but rice production is downturn and hardening price. Hence, needed to diversify food. Food diversification is a process of selecting food materials which is not depended on only one food type but it also on various food materials. Food diversification aims to find best of alternatives in food choice [3]. Food alternatives including rice, corn, cassava, potato, sago, sorghum, wheat, and analog rice. Food alternatives required to national food policy. Food alternatives must be health benefits. Health benefits including rich protein, low fat, normal carbohydrate, low Glycemix Index, rich fiber, normal energy, normal Ca, and normal Fe.

Health benefits of rice [4] is great source of energy, prevent Alzheimer's disease, excellent source of vitamins and minerals, cholesterol free and helps reduce obesity, best food for those suffering from hypertension, protect against the development of cancerous cells, provides relief from diarrhea and irritable bowl syndrome, and husk of rice effectively, and treats dysentery. Health benefits of corn [5] is lowers risk of colon cancer, rich source vitamins and minerals, controls diabetes hypertension, reduces cholesterol absorption in body, prevents anemia, reduces risk of various cardiovascular diseases, boosts immune system, helps maintain good vision and skin, reduces risk of hemmorhoids and improves bone strength. Health benefits of cassava [6] is aids in digestion, helps to prevent birth defects, aids in healthy weight gain, helps to enhance energy levels, reduces risk of Alzheimer's disease, helps to protect and develope bones, beneficial in improving blood circulation, reduces risk of cardiovascular disorders, useful for muscle growth and development, and helps in maintaining optimal blood pressure. Health benefits of potato [7] is prevent obesity, boosts immune system, helps in maintaining optimal blood pressure, reduces risk of various cardiovascular diseases, aids in digestion, helps maintain health skin, and brain optimal function. Health benefits of sago [8] is source of health food, lowers risk of intestinal cancer, prevent obesity, prevent constipation, improves bone strength and teeth. Health benefits of sorghum [9] is helps in managing diabetes, aids in improve digestive health, prevent atherosclerosis and strokes, beneficial in maintaining healthy bones, protect against osteoporosis and arthritis, reduces risk of cancer such esophageal cancer, boosts blood circulation and energy levels in body, helps to prevent cramping, bloating constipation, excess gass and diarrhea. Health benefits of wheat [9] is helps control obesity, reduces risk of type 2 diabetes, protect against breast and colon cancer, reduces bile acid secretion, helps improve gastrointestinal health in women, protect against chilhood asthma, lowers risk chronic inflammation, helps women to avoid gailstones, improve body metabolism, protect against coronary heart disease and heart attack.

Health benefits of analog rice [10] is lowers risk of diabetes and low fat. Analog rice (artificial rice) based flour indigenous as sorghum, sago, cassava, and other. Flour have scientifically proven have additional benefit to health, rich fiber, potentially as prebiotic, and low Glycemix Index (GI). The Glycemic Index (GI) is a scientific ranking of how the foods we eat affect our 
blood sugar levels in the 2 or 3 hours after eating. Foods are measured against pure glucose, which has a value of 100 on the index. The index ranges from 0 to 100 with: 0 $55=$ Low-GI, 56-69= Medium - GI, and 70-100 = HighGI. High GI is carbohydrates that break down quickly during digestion, release blood sugar rapidly into the bloodstream, causing rapid fluctuations in blood sugar levels. Medium GI is carbohydrates that break down moderately during digestion and release blood sugar moderately into the bloodstream. Low-GI : is carbohydrates that break down slowly during digestion, release blood sugar gradually into the bloodstream, and keep blood sugar levels steady. Pro-health behaviours in food choice, choice motives, preferences and food intake.

Rice, corn, cassava, potato, sago, sorghum, wheat and analog rice is multi-alternative in food choice. Multialternative can be optimal decision by using MultiAttribute Decision Making (MADM). MADM is one of the decision making methods to choose the alternative under multiple attributes [11]. Since a number of conflict factors are caused by the limited resources, MADM allows a decision maker to determine the factor among the variables with multi-attribute or the optimal environment to operation situation. To solve an MADM problem with a numerical approach, attempted to solve a problem with distance or fuzzy index, suggested the interactive approach to improve the method using multiobjective linier programming. However, it was hard to keep the consistency and to guarantee the optimal solution. Although the method can not only decide the optimal plant but also solve the MADM having mixed attributes, it is possible only if each attribute is independent.

Various MADM methods have been proposed to solve diverse applications of decision problems. One of MADM methods is Simple Additive Weighting (SAW). This method [12] is also known as a weighted linear combination or scoring method. It is simple and the most often method used multi- attribute decision technique. The method is based on the weighted average using arithmetic mean. An evaluation score can be calculated for each alternative by multiplying the scaled value given to the alternative of that attribute with the weights of relative importance directly assigned by the decision makers followed by summing of the products for all criteria. The advantage of SAW method is that it is a proportional linear transformation of the raw data. It means that the relative order of magnitude of the standardized scores remains equal. MADM methods have been proposed is Weighted Product (WP). This method [13] is more efficient than other methods in problem solving of MADM. The reason is because of the time needed in the calculation. This method stood by calculation simple, and easy to apply in cases having high subjectivity elements, effective to optimize decision problems.

\section{RELATED WORK}

In the paper [14], the pollution of the Surabaya River has increased along with the rapid development of the industry in Surabaya, Indonesia. This causes the water quality decreases Surabaya. The results are followed by Fuzzy Multi-Attribute Decision Making (MADM) to get the most polluted sites in times of Surabaya. The results from the this study by using SAW, WP and TOPSIS showed that location is the 5-th most polluted locations to produce value for each 32.2917, 0.1139, and 0.2753.

In the paper [15], DSS is an application that can assist students in determining the direction in senior high school (SMA) based on Multiple Intelligence tests using techniques MADM by the method of SAW and Analytical Hierarchy Process (AHP). The results of analysis system showed that the most influential factor in determining of the majors based on interest is the interest of students, academic grades, test psychologist and wishes of parents. Accuracy in the calculation of the value system based SAW method has an accuracy of $80 \%$ according to the student's choice. The decision by the AHP method has an accuracy of $30 \%$ in accordance with the student's choice.

In the paper [16], the change of geographical situation such as weather and climate make farmers difficult to prepare the land for suitable crop. Consequently they depend on rainwater rice field. This paper explain the use of Fuzzy Simple Additive Weighting (F-SAW) to rank the alternate crops suitable for planted in each sub district in South East Minahasa, Indonesia. The results of the analysis it can be concluded that the fuzzy simple additive weighting algorithms (SAW) can be used to determine the type of food crops grown on a given area by using a number of criteria such as soil texture, rainfall, irrigation, climate and topography.

In the paper [17], two methods of MADM have been used in this research, those are Weighted Product (WP) method and Technique of Order Preference by Similarity to Ideal Solution (TOPSIS) for the analysis medium in determining regional priority to development implementation in the future. The research by comparing the two methods are obtained six regencies which need special attention. This research also shows that the last step of calculation of preferency value for WP method was extremely influenced by completeness of beginning decision matrix value.

In the paper [18], consumer confusion is a phenomena when the consumer experiencing several confusion problems when she/he should to purchase products/services. Results of this study indicate that the Fuzzy SAW based Decision Support System (DSS) application has potential ability as an another alternatives of conventional Confusion Reduction Strategy (CRS) to reducing consumer confusion.

In the paper [19], integrated SAW and Sensitivity Analysis, Integrated SAW and TOPSIS, Integrated SAW (A, B, and C) ABC Analysis and Statistical Clustering, Integrated SAW, TOPSIS and Artificial Neural Network (ANN) method, Integrated FSAW and FAHP, Integrated FSAW, Delphi Method and Fuzzy Linguistic Evaluation, Integrated FSAW, FAHP and FTOPSIS, and Integrated FSAW under T-numbers. In this paper, nineteen journal 
articles, which appeared in the period of 2003 until 2013, using the SAW and FSAW models are collected (searched via IEEE Xplore, Science Direct, Springer and Wiley). The advantage of SAW method is that it is a proportional linear transformation of the raw data. It means that the relative order of magnitude of the standardized scores remains equal. Most of the articles discussed SAW and FSAW and its applications to various application domains including supply chain management, personnel selection problems, project manager selection and facility location selection. The review classified the published articles into individual approaches and integrated approaches.

\section{FUNDAMENTAL THEORY}

\section{A. Multi-Attribute Decision Making}

Multi-Attribute Decision Making (MADM) refers to screening, prioritizing, ranking, or selecting a set of alternatives usually under independent, incommensurate or conflicting attributes [20]. A MADM problem can be concisely expressed in the matrix format as shown below:

$$
\begin{gathered}
A=\left\{a_{i} \mid i=1,2,3, \ldots, n\right\} \\
C=\left\{c_{j} \mid j=1,2,3, \ldots, m\right\} \\
W=\left\{W_{1}, W_{2}, W_{3}, \ldots, W_{n}\right\} \\
X=\left[\begin{array}{cccc}
x_{11} & x_{12} & \ldots & x_{1 n} \\
x_{21} & x_{22} & \ldots & x_{2 n} \\
\vdots & \vdots & & \vdots \\
x_{m 1} & x_{m 2} & \ldots & x_{m n}
\end{array}\right]
\end{gathered}
$$

where $A_{l}, A_{2}, \ldots, A_{m}$ are feasible alternatives, $C_{l}, C_{2}, \ldots, C_{n}$ are attributes (criteria), $x_{i j}$ is the performance rating of $i$-th alternative with respect to $j$-th attribute, and $w_{j}$ is a weight (significance) of $j$-th attribute.

In a typical MADM evaluation, attributes can be classified into two main categories: cost attributes and benefit attributes. In the case of benefit attributes, the higher score is assigned to the alternative which performance rating is higher, i.e., preferable is a maximum of $j$-th attribute. In contrast to the previous, in the case of cost attributes, higher score is assigned to the alternative which performance rating is lower, i.e., the minimum of $j$-th attribute is preferable.

There are three approaches to find the value of weight an attribute, namely subjective approach, objective approach and integration approach. Integration approach between subjective approach and objective approach. Each approach has advantages and disadvantages. On the subjective approach, weighting value is determined based on decision makers, so some of the factors in the process of rank alternative can be determined freely. On the objective approach, value of weight calculated mathematically, so ignore subjective from the decision makers. In this paper using integration between objective approach and subjective approach.

\section{B. Simple Additive Weighting}

Simple Additive Weighting (SAW) method is probably the best known and most widely used MADM method [20]. SAW method also known as scoring method is one of the best and simplest type of multiple attribute decision making method. The basic logic of the SAW method is to obtain a weighted sum of performance ratings of each alternative over all attributes. The step wise procedure is given below:

$$
A=\left(a_{1}, a_{2}, a_{3}, \ldots, a_{n}\right)
$$

Let $A=\left(a_{1}, a_{2}, a_{3}, \ldots, a_{n}\right)$ be a set on alternatives.

$$
C=\left(c_{1}, c_{2}, c_{3}, \ldots, c_{n}\right)
$$

Let $C=\left(c_{1}, c_{2}, c_{3}, \ldots ., c_{n}\right)$ be a set of criteria.

- Step 1: Construct the decision matrix:

$$
\begin{array}{llll}
d_{11} & d_{12} & \ldots & d_{1 n} \\
d_{21} & d_{22} & \ldots & d_{2 n} \\
\cdots & \cdots & \cdots & \cdots \\
d_{n 1} & d_{n 2} & \cdots & d_{n n}
\end{array}
$$

Where dij is the rating of alternative $\mathrm{Ai}$ with respect to criterion $\mathrm{Ci}$.

- Step 2: Construct the normalized decision matrix. For beneficial attribute (criteria of benefit):

$$
r_{i j}=\frac{d_{i j}}{d_{i j}^{\max }}
$$

For non beneficial attribute (criteria of cost):

$$
r_{i j}=\frac{d_{i j}^{\text {min }}}{d_{i j}}
$$

- Step 3: Construct weighted normalized decision matrix.

$$
V_{i j}=W_{i j} * r_{i j}, \sum_{i=1}^{n} W_{i}=1
$$

- $\quad$ Step 4: Calculate the score of each alternative.

$$
S_{i}=\sum_{j=1}^{m} V_{i j}, i=1,2,3, \ldots, n
$$


- $\quad$ Step 5: Select the best alternative.

$$
B A_{\text {Saw }}=\max { }_{i=1}^{n} S_{i}
$$

Where BA saw is Best Alternative in Simple Additive Weighting (SAW) method and $S_{i}$ is matrix score.

\section{Weighted Product}

Weighted Product (WP) method [20] is another scoring method where the weighted product of the criterion is used to select the best alternative.

The step wise procedure is given below:

- $\quad$ Step 1: identical to SAW method.

- Step 2: identical to SAW method.

- Step 3: Construct weighted normalized decision matrix.

$$
V_{i j}=\mathbb{r}_{i j}{ }^{W_{i j}}
$$

- Step 4: Calculate the score of each alternative.

$$
M_{i}=\prod_{j=1}^{m} V_{i j}
$$

- $\quad$ Step 5: Select the best alternative.

$$
B A_{w p}=\max { }_{i=1}^{n} M_{i}
$$

Where $B A w p$ is Best Alternative in Weighted Product (WP) method and $M$ is matrix score.

\section{FRAMEWORK}

In this paper, framework can be depicted as shown in Figure 1.

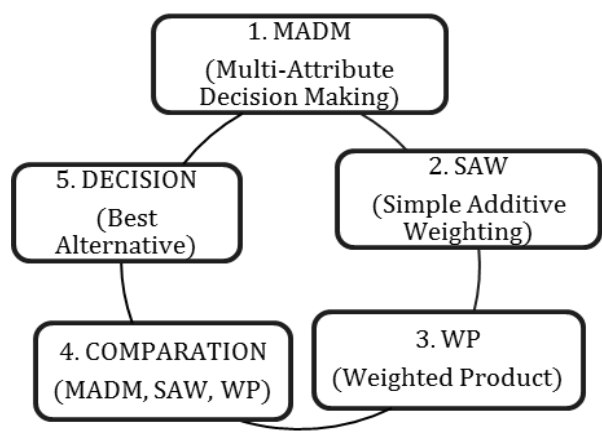

Fig.1. Framework

Figure 1 shows framework in decision model. Framework is 5 step. Step 1, MADM as decision model. Step 2, SAW as method in MADM. Step 3, WP as method in MADM 2. Step 4, Comparation SAW and WP. Step 5, Decision in MADM, result of SAW method and
WP method is best alternative on decision model.

\section{RESULT AND DiSCUSSION}

\section{A. Multi-Attribute Decision Making}

Food criteria, symbol, attribute criteria, and food alternative can be seen on Table 1 .

Table 1. Criteria, Attribute and Alternative

\begin{tabular}{|l|l|l|l|l|}
\hline $\begin{array}{l}\text { Food } \\
\text { Criteria }\end{array}$ & Symbol & $\begin{array}{l}\text { Attribute } \\
\text { Category }\end{array}$ & $\begin{array}{l}\text { Food } \\
\text { Alternatives }\end{array}$ & Symbol \\
\hline Protein & C1 & Benefit & Rice & A1 \\
\hline Fat & C2 & Cost & Corn & A2 \\
\hline Carbohydrate & C3 & Benefit & Cassava & A3 \\
\hline Glycemix & C4 & Cost & Potato & A4 \\
\hline Fiber & C5 & Benefit & Sago & A5 \\
\hline Energy & C6 & Benefit & Sorghum & A6 \\
\hline Ca & C7 & Benefit & Wheat & A7 \\
\hline Fe & C8 & Benefit & Analog Rice & A8 \\
\hline
\end{tabular}

Table 1 shows 8 criteria and 8 alternative in MADM. Attribute can be classified into two main categories: benefit attributes (6 attribute) and cost attributes (2 attribute). Food alternatives, content of nutrition and its composition (BKP Deptan 08, nutrition fact and its processing), shown on Table 2.

Table 2. Composition of Food Alternatives

\begin{tabular}{|l|c|c|c|c|}
\hline $\begin{array}{l}\text { Food } \\
\text { Alternatives }\end{array}$ & $\begin{array}{c}\text { Protein } \\
(\mathrm{g})\end{array}$ & Fat $(\mathrm{g})$ & $\begin{array}{c}\text { Carbo } \\
\text { hydrate }(\mathrm{g})\end{array}$ & $\begin{array}{c}\text { Fiber } \\
(\mathrm{g})\end{array}$ \\
\hline Rice & 7.90 & 2.70 & 76.00 & 1.00 \\
\hline Corn & 9.20 & 4.60 & 73.00 & 2.80 \\
\hline Cassava & 1.36 & 0.28 & 38.06 & 0.90 \\
\hline Potato & 2.02 & 0.09 & 17.47 & 2.50 \\
\hline Sago & 0.70 & 0.20 & 85.00 & 0.50 \\
\hline Sorghum & 10.40 & 3.10 & 70.70 & 2.00 \\
\hline Wheat & 11.60 & 2.00 & 71.00 & 2.00 \\
\hline Analog Rice & 0.66 & 5.66 & 82.28 & 2.80 \\
\hline \multicolumn{5}{|c|}{$(\mathrm{continued})$} \\
\hline Food & $\begin{array}{c}\text { Glycemix } \\
\text { Alternatives }\end{array}$ & $\begin{array}{c}\text { Energy } \\
(\mathrm{kcal})\end{array}$ & $\begin{array}{c}\text { Ca } \\
(\mathrm{mg})\end{array}$ & $\begin{array}{c}\text { Fe } \\
(\mathrm{mg})\end{array}$ \\
\hline Rice & 91.00 & 362.00 & 33.00 & 1.80 \\
\hline Corn & 72.00 & 358.00 & 26.00 & 2.70 \\
\hline Cassava & 96.46 & 180.00 & 33.00 & 30.00 \\
\hline Potato & 67.71 & 77.00 & 11.00 & 1.00 \\
\hline Sago & 51.00 & 353.00 & 10.00 & 1.20 \\
\hline Sorghum & 32.00 & 329.00 & 25.00 & 5.40 \\
\hline Wheat & 68.00 & 348.00 & 30.00 & 3.50 \\
\hline Analog Rice & 44.19 & 378.00 & 33.00 & 1.80 \\
\hline
\end{tabular}

Table 2 shows composition of nutrition from food alternatives. Content of nutrition on food alternatives, value and feasible alternatives as weight of criteria (value) based on health benefits.

Food attribute, value of attribute, and attribute category can be seen on Table 3 . 
Table 3. Attribute, Value and Category

\begin{tabular}{|c|c|c|c|c|c|}
\hline $\begin{array}{c}\text { Food } \\
\text { Attribute }\end{array}$ & $\begin{array}{c}\text { Value } \\
\text { of } \\
\text { Attribute }\end{array}$ & $\begin{array}{l}\text { Attribute } \\
\text { Category }\end{array}$ & $\begin{array}{c}\text { Food } \\
\text { Attribute }\end{array}$ & $\begin{array}{c}\text { Value } \\
\text { of } \\
\text { Attribute }\end{array}$ & $\begin{array}{l}\text { Attribute } \\
\text { Category }\end{array}$ \\
\hline $\begin{array}{l}\text { Rich Protein } \\
=3\end{array}$ & $\begin{array}{l}1=\text { low } \\
2=\text { sufficient } \\
3=\text { rich }\end{array}$ & Benefit & $\begin{array}{c}\text { Rich Fiber } \\
=3\end{array}$ & \begin{tabular}{|l}
$1=$ less \\
$2=$ sufficient \\
$3=$ rich
\end{tabular} & Benefit \\
\hline $\begin{array}{l}\text { Low } \\
\text { Fat } \\
=3\end{array}$ & $\begin{array}{l}3=\text { low } \\
2=\text { sufficient } \\
1=\text { high }\end{array}$ & Cost & $\begin{array}{l}\text { Normal } \\
\text { Energy } \\
=2\end{array}$ & $\begin{array}{l}1=\text { less } \\
2=\text { sufficient } \\
3=\text { excessive }\end{array}$ & Benefit \\
\hline $\begin{array}{c}\text { Normal } \\
\text { Carbo } \\
\text { Hydrate }=2\end{array}$ & $\begin{array}{l}1=\text { less } \\
2=\text { sufficient } \\
3=\text { hight }\end{array}$ & Benefit & $\begin{array}{c}\text { Normal Ca } \\
=2\end{array}$ & \begin{tabular}{|l}
$1=$ less \\
$2=$ sufficient \\
$3=$ excessive
\end{tabular} & Benefit \\
\hline $\begin{array}{l}\text { Low } \\
\text { Glycemic } \\
\text { Index } \\
=3\end{array}$ & $\begin{array}{l}3=\text { low } \\
2=\text { sufficient } \\
1=\text { high }\end{array}$ & Cost & $\begin{array}{l}\text { Normal Fe } \\
\quad=2\end{array}$ & $\begin{array}{l}1=\text { less } \\
2=\text { sufficient } \\
3=\text { excessive }\end{array}$ & Benefit \\
\hline
\end{tabular}

Table 3 shows food attribute with feasible alternatives based on health benefits, best value of attribute, and attribute category (criteria of benefit and criteria of cost). Food attribute, value of attribute, attribute category to determine score of weight.

\section{B. Simple Additive Weighting}

Decision maker given weight, displayed on Table 4.

Table 4. Weight of Criteria on MADM

\begin{tabular}{|c|c|c|}
\hline Criteria & Weight & Conversion \\
\hline C1 & 15.00 & 0.15 \\
\hline C2 & 10.00 & 0.10 \\
\hline C3 & 12.50 & 0.125 \\
\hline C4 & 10.00 & 0.10 \\
\hline C5 & 15.00 & 0.15 \\
\hline C6 & 12.50 & 0.125 \\
\hline C7 & 12.50 & 0.125 \\
\hline C8 & 12.50 & 0.125 \\
\hline Total & $100 \%$ & $100 \%$ \\
\hline
\end{tabular}

Table 4 shows weight of criteria and conversion in calculating decision matrix, normalized matrix, and score of each alternative.

- Step 1: Construct the decision matrix. Decision matrix displayed on Table 5.

Table 5. Decision Matrix on SAW

\begin{tabular}{|c|c|c|c|c|c|c|c|}
\hline $\mathrm{d}_{11=2}$ & $\mathrm{~d}_{12=2}$ & $\mathrm{~d}_{13=3}$ & $\mathrm{~d}_{14=2}$ & $\mathrm{~d}_{15=1}$ & $\mathrm{~d}_{16=3}$ & $\mathrm{~d}_{17=3}$ & $\mathrm{~d}_{18=1}$ \\
\hline $\mathrm{d}_{21=3}$ & $\mathrm{~d}_{22=3}$ & $\mathrm{~d}_{23=3}$ & $\mathrm{~d}_{24=3}$ & $\mathrm{~d}_{25=3}$ & $\mathrm{~d}_{26=3}$ & $\mathrm{~d}_{27=2}$ & $\mathrm{~d}_{28=2}$ \\
\hline $\mathrm{d}_{31=1}$ & $\mathrm{~d}_{32=1}$ & $\mathrm{~d}_{33=2}$ & $\mathrm{~d}_{34=3}$ & $\mathrm{~d}_{35=2}$ & $\mathrm{~d}_{36=2}$ & $\mathrm{~d}_{37=2}$ & $\mathrm{~d}_{38=3}$ \\
\hline $\mathrm{d}_{41=1}$ & $\mathrm{~d}_{42=1}$ & $\mathrm{~d}_{43=2}$ & $\mathrm{~d}_{44=1}$ & $\mathrm{~d}_{45=2}$ & $\mathrm{~d}_{46=1}$ & $\mathrm{~d}_{47=3}$ & $\mathrm{~d}_{48=2}$ \\
\hline $\mathrm{d}_{51=1}$ & $\mathrm{~d}_{52=2}$ & $\mathrm{~d}_{53=2}$ & $\mathrm{~d}_{54=3}$ & $\mathrm{~d}_{55=2}$ & $\mathrm{~d}_{56=2}$ & $\mathrm{~d}_{57=2}$ & $\mathrm{~d}_{58=1}$ \\
\hline $\mathrm{d}_{61=3}$ & $\mathrm{~d}_{62=3}$ & $\mathrm{~d}_{63=3}$ & $\mathrm{~d}_{64=2}$ & $\mathrm{~d}_{65=3}$ & $\mathrm{~d}_{66=3}$ & $\mathrm{~d}_{67=2}$ & $\mathrm{~d}_{68=3}$ \\
\hline $\mathrm{d}_{71=3}$ & $\mathrm{~d}_{72=2}$ & $\mathrm{~d}_{73=3}$ & $\mathrm{~d}_{74=2}$ & $\mathrm{~d}_{75=3}$ & $\mathrm{~d}_{76=3}$ & $\mathrm{~d}_{77=3}$ & $\mathrm{~d}_{78=3}$ \\
\hline $\mathrm{d}_{81=3}$ & $\mathrm{~d}_{82=2}$ & $\mathrm{~d}_{83=2}$ & $84=3$ & $\mathrm{~d}_{85=3}$ & $\mathrm{~d}_{86=3}$ & $\mathrm{~d}_{87=2}$ & $\mathrm{~d}_{88=2}$ \\
\hline
\end{tabular}

Table 5 shows decision matrix $\left(\mathrm{d}_{\mathrm{ij}}\right)$ is the rating of alternative with respect to criteria based Table 2 (food composition) and Table 3 (value of attribute).

- Step 2: Construct the normalized decision matrix, displayed on Table 6.
Table 6. Normalized Decision Matrix on SAW

\begin{tabular}{|l|l|}
\hline$r_{11}=\frac{2}{\max \{2 ; 3 ; 1 ; 1 ; 1 ; 3 ; 3 ; 3\}}=\frac{2}{3}=0.667$ & $r_{15}=\frac{1}{\max \{1 ; 3 ; 2 ; 2 ; 2 ; 3 ; 3 ; 3\}}=\frac{1}{3}=0.33$ \\
\hline$r_{12}=\frac{\min \{2 ; 3 ; 1 ; 1 ; 2 ; 3 ; 2 ; 2\}}{2}=\frac{1}{2}=0.5$ & $r_{16}=\frac{3}{\max \{3 ; 3 ; 2 ; 1 ; 2 ; 3 ; 3 ; 3\}}=\frac{3}{3}=1$ \\
\hline$r_{13}=\frac{3}{\max \{3 ; 3 ; 2 ; 2 ; 2 ; 3 ; 3 ; 2\}}=\frac{3}{3}=1$ & $r_{17}=\frac{3}{\max \{3 ; 2 ; 2 ; 3 ; 2 ; 2 ; 3 ; 2\}}=\frac{3}{3}=1$ \\
\hline$r_{14}=\frac{\min \{2 ; 3 ; 3 ; 1 ; 3 ; 2 ; 2 ; 3\}}{2}=\frac{1}{2}=0.5$ & $r_{18}=\frac{3}{\max \{3 ; 2 ; 2 ; 3 ; 2 ; 2 ; 3 ; 2\}}=\frac{3}{3}=1$ \\
\hline
\end{tabular}

Table 6 shows rating $\left(\mathrm{r}_{\mathrm{ij}}\right)$ normalized decision matrix for attribute category (criteria of benefit and criteria of cost). Criteria of benefit with value $\left(\mathrm{r}_{\mathrm{ij}} \max \right)$ and criteria of cost with valu $\left(\mathrm{r}_{\mathrm{ij}} \mathrm{min}\right)$ based on decision matrix with process is value each of decision matrix $\left(\mathrm{d}_{\mathrm{ij}}\right)$ divided by maximum value of all decision matrix $\left(\mathrm{d}_{\mathrm{ij}}\right.$ in first column, and so on).

- Step 3: Construct weight normalized decision matrix, displayed on Table 7.

Table 7. Weight Normalized Decision Matrix On SAW

\begin{tabular}{|c|l|}
\hline No & \multicolumn{1}{|c|}{$\mathrm{V}_{\mathrm{ij}}$} \\
\hline 1 & $\begin{array}{l}v_{1}=(0,15 * 0,667)+(0,10 * 0,5)+(0,125 * 1)+(0,10 * 0,5)+ \\
(0,15 * 0,33)+(0,125 * 1)+(0,125 * 1)+(0,125 * 1)=0.7495\end{array}$ \\
\hline 2 & $\begin{array}{l}v_{2}=(0,15 * 1)+(0,10 * 0,33)+(0,125 * 1)+(0,10 * 0,33)+ \\
(0,15 * 1)+(0,125 * 1)+(0,125 * 0,667)+(0,125 * 0,667)=0.7827\end{array}$ \\
\hline 3 & $\begin{array}{l}v_{3}=(0,15 * 0,33)+(0,10 * 1)+(0,125 * 0,667)+(0,10 * 0,33)+ \\
(0,15 * 0,667)+(0,125 * 0,667)+(0,125 * 0,667)+(0,125 * 1)=0.6576\end{array}$ \\
\hline 4 & $\begin{array}{l}v_{4}=(0,15 * 0,33)+(0,10 * 1)+(0,125 * 0,667)+(0,10 * 0,33)+ \\
(0,15 * 0,667)+(0,125 * 0,33)+(0,125 * 1)+(0,125 * 0,33)=0.8704\end{array}$ \\
\hline 5 & $\begin{array}{l}v_{5}=(0,15 * 0,33)+(0,10 * 0,5)+(0,125 * 0,667)+(0,10 * 0,33)+ \\
(0,15 * 0,667)+(0,125 * 0,667)+(0,125 * 0,667)+(0,125 * 0,33)=0.5824\end{array}$ \\
\hline 6 & $\begin{array}{l}v_{6}=(0,15 * 1)+(0,10 * 0,33)+(0,125 * 1)+(0,10 * 0,5)+ \\
(0,15 * 1)+(0,125 * 1)+(0,125 * 0,667)+(0,125 * 1)=0.8413\end{array}$ \\
\hline 7 & $\begin{array}{l}v_{7}=(0,15 * 1)+(0,10 * 0,5)+(0,125 * 1)+(0,10 * 0,5)+ \\
(0,15 * 1)+(0,125 * 1)+(0,125 * 1)+(0,125 * 1)=0.8833\end{array}$ \\
\hline 8 & $\begin{array}{l}v_{8}=(0,15 * 1)+(0,10 * 0,5)+(0,125 * 1)+(0,10 * 0,33)+ \\
(0,15 * 1)+(0,125 * 1)+(0,125 * 0,667)+(0,125 * 0,667)=0.7997\end{array}$ \\
\hline
\end{tabular}

Table 7 shows value $\left(\mathrm{v}_{\mathrm{ij}}\right)$ weight normalized decision matrix with process is conversion of weight on Table 4 multiply by $\mathrm{r}_{\mathrm{ij}}$ on Table 6 .

- Step 4: Calculate the score of each alternative, displayed on Table 8.

Table 8. Score of Each Alternative on SAW

\begin{tabular}{|c|c|c|l|}
\hline No & $\mathrm{v}_{\mathrm{ij}}$ & Score & Food Alternative \\
\hline 1 & $\mathrm{v}_{1}$ & 0.7495 & Rice \\
\hline 2 & $\mathrm{v}_{2}$ & 0.7827 & Corn \\
\hline 3 & $\mathrm{v}_{3}$ & 0.6576 & Cassava \\
\hline 4 & $\mathrm{v}_{4}$ & 0.8704 & Potato \\
\hline 5 & $\mathrm{v}_{5}$ & 0.5824 & Sago \\
\hline 6 & $\mathrm{v}_{6}$ & 0.8413 & Sorghum \\
\hline 7 & $\mathrm{v}_{7}$ & 0.8833 & Wheat \\
\hline 8 & $\mathrm{v}_{8}$ & 0.7997 & Analog Rice \\
\hline
\end{tabular}

- Step 5: Select the best alternative, displayed on Table 9. 
Table 9. Best Alternative on SAW

\begin{tabular}{|c|c|c|c|c|c|l|}
\hline No & $\left(\mathrm{v}_{\mathrm{ij}}\right)$ & Score & No & $\left(\mathrm{v}_{\mathrm{ij}}\right)$ & Score & Food Alternative \\
\hline 1 & $\mathrm{v}_{1}$ & 0.7495 & 1 & $\mathrm{v}_{7}$ & 0,8833 & Wheat \\
\hline 2 & $\mathrm{v}_{2}$ & 0.7827 & 2 & $\mathrm{v}_{4}$ & 0,8704 & Potato \\
\hline 3 & $\mathrm{v}_{3}$ & 0.6576 & 3 & $\mathrm{v}_{6}$ & 0,8413 & Sorghum \\
\hline 4 & $\mathrm{v}_{4}$ & 0.8704 & 4 & $\mathrm{v}_{8}$ & 0,7997 & Analog Rice \\
\hline 5 & $\mathrm{v}_{5}$ & 0.5824 & 5 & $\mathrm{v}_{2}$ & 0,7827 & Corn \\
\hline 6 & $\mathrm{v}_{6}$ & 0.8413 & 6 & $\mathrm{v}_{1}$ & 0,7495 & Rice \\
\hline 7 & $\mathrm{v}_{7}$ & 0.8833 & 7 & $\mathrm{v}_{3}$ & 0,6576 & Cassava \\
\hline 8 & $\mathrm{v}_{8}$ & 0.7997 & 8 & $\mathrm{v}_{5}$ & 0,5824 & Sago \\
\hline
\end{tabular}

Table 9 shows highest value is alternative on $\mathrm{v}_{7}$, so alternative $\mathrm{A}_{7}$ (wheat) is chosen as the best alternative.

\section{Weighted Product}

Weighted Product (WP) method using process of normalization with process is value of each attribute multiply by weight attribute.

- Step 1: identical to SAW method.

- Step 2: Construct normalized decision matrix, displayed on Table 10.

Table 10. Normalized Decision Matrix on WP

\begin{tabular}{|c|l|}
\hline No & $\mathrm{S}_{\mathrm{i}}$ \\
\hline 1 & $S_{1}=\left(2^{0,15}\right)\left(2^{-0,10}\right)\left(3^{0,125}\right)\left(2^{-0,10}\right)\left(1^{0,15}\right)\left(3^{0,125}\right)\left(3^{0,125}\right)\left(1^{0,125}\right)=1.9239$ \\
\hline 2 & $S_{2}=\left(3^{0,15}\right)\left(3^{-0,10}\right)\left(3^{0,125}\right)\left(3^{-0,10}\right)\left(3^{0,15}\right)\left(3^{0,125}\right)\left(2^{0,125}\right)\left(2^{0,125}\right)=2.7104$ \\
\hline 3 & $S_{3}=\left(1^{0,15}\right)\left(1^{-0,10}\right)\left(2^{0,125}\right)\left(3^{-0,10}\right)\left(2^{0,15}\right)\left(2^{0,125}\right)\left(2^{0,125}\right)\left(3^{0,125}\right)=1.8422$ \\
\hline 4 & $S_{4}=\left(1^{0,15}\right)\left(1^{-0,10}\right)\left(2^{0,125}\right)\left(1^{-0,10}\right)\left(2^{0,15}\right)\left(1^{0,125}\right)\left(3^{0,125}\right)\left(2^{0,125}\right)=1.5136$ \\
\hline 5 & $S_{5}=\left(1^{0,15}\right)\left(2^{-0,10}\right)\left(2^{0,125}\right)\left(3^{-0,10}\right)\left(2^{0,15}\right)\left(2^{0,125}\right)\left(2^{0,125}\right)\left(1^{0,125}\right)=1.7209$ \\
\hline 6 & $S_{6}=\left(3^{0,15}\right)\left(3^{-0,10}\right)\left(3^{0,125}\right)\left(2^{-0,10}\right)\left(3^{0,15}\right)\left(3^{0,125}\right)\left(2^{0,125}\right)\left(3^{0,125}\right)=2.7379$ \\
\hline 7 & $S_{7}=\left(3^{0,15}\right)\left(2^{-0,10}\right)\left(3^{0,125}\right)\left(2^{-0,10}\right)\left(3^{0,15}\right)\left(3^{0,125}\right)\left(3^{0,125}\right)\left(3^{0,125}\right)=2.7656$ \\
\hline 8 & $S_{8}=\left(3^{0,15}\right)\left(2^{-0,10}\right)\left(2^{0,125}\right)\left(3^{-0,10}\right)\left(3^{0,15}\right)\left(3^{0,125}\right)\left(2^{0,125}\right)\left(2^{0,125}\right)=2.4739$ \\
\hline
\end{tabular}

Table 10 shows score $\left(\mathrm{S}_{\mathrm{i}}\right)$ on each alternative with process value of decision matrix $\left(\mathrm{d}_{\mathrm{ij}}\right)$ on Table 5 squared by weight conversion on Table 4 based on decision makers.

- Step 3: Construct weight normalized decision matrix, displayed on Table 11.

Table 11. Weight Normalized Decision Matrix on WP

\begin{tabular}{|c|l|}
\hline No & $V_{1}=\frac{V_{\mathrm{ij}}}{1,9239+2,7104+1,8422+1,5136+1,7209+2,7379+2,7656+2,4739}=0.1087$ \\
\hline 2 & $V_{2}=\frac{2,7104}{1,9239+2,7104+1,8422+1,5136+1,7209+2,7379+2,7656+2,4739}=0.1532$ \\
\hline 3 & $V_{3}=\frac{1,8422}{1,9239+2,7104+1,8422+1,5136+1,7209+2,7379+2,7656+2,4739}=0.1041$ \\
\hline 4 & $V_{4}=\frac{1,5136}{1,9239+2,7104+1,8422+1,5136+1,7209+2,7379+2,7656+2,4739}=0.0855$ \\
\hline 5 & $V_{5}=\frac{1,7209}{1,9239+2,7104+1,8422+1,5136+1,7209+2,7379+2,7656+2,4739}=0.0972$ \\
\hline 6 & $V_{6}=\frac{2,7379}{1,9239+2,7104+1,8422+1,5136+1,7209+2,7379+2,7656+2,4739}=0.1547$ \\
\hline 7 & $V_{7}=\frac{2,7656}{1,9239+2,7104+1,8422+1,5136+1,7209+2,7379+2,7656+2,4739}=0.1563$ \\
\hline 8 & $V_{8}=\frac{2,4739}{1,9239+2,7104+1,8422+1,5136+1,7209+2,7379+2,7656+2,4739}=0.1398$ \\
\hline
\end{tabular}

Table 11 shows value $\left(\mathrm{v}_{\mathrm{ij}}\right)$ weight normalized matrix with process is score each of alternative $\left(\mathrm{S}_{\mathrm{i}}\right)$ multiply by sum of all of score.

- Step 4: Calculate the score of each alternative, dispalyed on Table 12.

Table 12. Score of Each Alternative on WP

\begin{tabular}{|c|c|c|l|}
\hline No & $\mathrm{v}_{\mathrm{ij}}$ & Score & Food Alternative \\
\hline 1 & $\mathrm{v}_{1}$ & 0.1087 & Rice \\
\hline 2 & $\mathrm{v}_{2}$ & 0.1532 & Corn \\
\hline 3 & $\mathrm{v}_{3}$ & 0.1041 & Cassava \\
\hline 4 & $\mathrm{v}_{4}$ & 0.0855 & Potato \\
\hline 5 & $\mathrm{v}_{5}$ & 0.0972 & Sago \\
\hline 6 & $\mathrm{v}_{6}$ & 0.1547 & Sorghum \\
\hline 7 & $\mathrm{v}_{7}$ & 0.1563 & Wheat \\
\hline 8 & $\mathrm{v}_{8}$ & 0.1398 & Analog Rice \\
\hline
\end{tabular}

Table 12 shows score of each alternative on WP method for food alternative in MADM.

- Step 5: Select the best alternative, displayed on Table 13.

Table 13. Best Alternative on WP

\begin{tabular}{|c|c|c|c|c|l|}
\hline No & $\left(\mathrm{v}_{\mathrm{ij}}\right)$ & Score & $\left(\mathrm{v}_{\mathrm{ij}}\right)$ & Score & Alternative \\
\hline 1 & $\mathrm{v}_{1}$ & 0.1087 & $\mathrm{v}_{7}$ & 0.1563 & Wheat \\
\hline 2 & $\mathrm{v}_{2}$ & 0.1532 & $\mathrm{v}_{6}$ & 0.1547 & Sorghum \\
\hline 3 & $\mathrm{v}_{3}$ & 0.1041 & $\mathrm{v}_{2}$ & 0.1532 & Corn \\
\hline 4 & $\mathrm{v}_{4}$ & 0.0855 & $\mathrm{v}_{8}$ & 0.1398 & Analog Rice \\
\hline 5 & $\mathrm{v}_{5}$ & 0.0972 & $\mathrm{v}_{1}$ & 0.1087 & Rice \\
\hline 6 & $\mathrm{v}_{6}$ & 0.1547 & $\mathrm{v}_{3}$ & 0.1041 & Cassava \\
\hline 7 & $\mathrm{v}_{7}$ & 0.1563 & $\mathrm{v}_{5}$ & 0.0972 & Sago \\
\hline 8 & $\mathrm{v}_{8}$ & 0.1398 & $\mathrm{v}_{4}$ & 0.0855 & Potato \\
\hline
\end{tabular}

Table 13 shows highest value is alternative on $v_{7}$, so alternative $A_{7}$ (wheat) is chosen as the best alternative. Best alternative is wheat (highest score), with process is comparing and re-sequencing score of each alternative based on high value until low value of $v_{\mathrm{ij}}$.

\section{Comparation}

Comparation between food alternative on MADM, food alternative on SAW, food alternative on WP, displayed in Table 13.

Table 14. Comparation of Food Alternative

\begin{tabular}{|l|l|l|l|l|l|}
\hline No & $\begin{array}{l}\text { Food } \\
\text { Alternative } \\
\text { on MADM }\end{array}$ & No & $\begin{array}{l}\text { Food } \\
\text { Alternative } \\
\text { on SAW }\end{array}$ & No & $\begin{array}{l}\text { Food } \\
\text { Alternative } \\
\text { on WP }\end{array}$ \\
\hline 1 & Rice & 1 & Wheat & 1 & Wheat \\
\hline 2 & Corn & 2 & Potato & 2 & Sorghum \\
\hline 3 & Cassava & 3 & Sorghum & 3 & Corn \\
\hline 4 & Potato & 4 & Analog Rice & 4 & Analog Rice \\
\hline 5 & Sago & 5 & Corn & 5 & Rice \\
\hline 6 & Sorghum & 6 & Rice & 6 & Cassava \\
\hline 7 & Wheat & 7 & Cassava & 7 & Sago \\
\hline 8 & Analog Rice & 8 & Sago & 8 & Potato \\
\hline
\end{tabular}

Table 14 shows food alternative for each method with process is sequencial based on high score until low score. Food alternative on MADM with the best alternative is rice. Food alternative on SAW with the best alternative is 
wheat. Food alternative on WP with the best alternative is wheat.

\section{E. Decision}

Alternative on MADM as data training, alternative on SAW and alternative on WP as data testing. On SAW method, experimental result with best alternative (high value) is wheat with value 0.8833 . On WP method, experimental result with best alternative (high value) is wheat with value 0.1563 . MADM using SAW and WP in food choice result is wheat as best alternative.

\section{CONCLUSION}

The core of MADM is to determine the value of the weights to each attribute, continued with a rank who will select alternate already given. Alternative on MADM as data training, alternative on SAW and alternative on WP as data testing. From the speed, WP method faster than SAW method, in determining value or weight of each criteria. From the calculation, SAW method and WP method resulting decision or recommendation based on criteria food alternatives with the highest value. On SAW method, experimental result with best alternative (high value) is wheat with value 0.8833 . On WP method, experimental result with best alternative (high value) is wheat with $\mathrm{V}$ value 0.1563 . For the future work, how to decision making in MADM with multi-goal.

\section{REFERENCES}

[1] J. Mariyono, "The economic performance of indonesian rice-based agribusiness", International Journal of Administrative Science \& Organizaton, Vol. 21, No. 1, pp. 35-43, 2014.

[2] A. Ridhawanah, Z. Lubis, and E. Nasution, "A study of food consumption and nutritional status on street children in medan city 2014", Publich Health Journal, pp. 1-9, 2015.

[3] R. H. Puspadewi, and D. Briawan, "Perception of healthy food, motives food choice and healthy eating of undergraduate students", Nutrition and Food Journal, Vol. 9, No. 3, pp. 211-218, 2014.

[4] Bhat F. M, Riar C. S, "Health benefits of traditional rice varieties of temperate regions", Med. Aromat Plants 4: 198, Vol. 4, Issue 3, 2015.

[5] M. Ismayanti, and Harijono, "Formulation of complementary feeding based on germinated cowpea flour and corn using linear programming", Agro-Industry and Food Journal, Vol. 3, No. 3, pp. 996-1005, 2015.

[6] Tonukari, N.J., Ezedom, T., Enuma, C.C., Sakpa, S.O., Avwioroko, O.J., Eraga, L. and Odiyoma, E. "White gold: cassava as an industrial base", American Journal of Plant Sciences, Vol. 6, pp. 972-979, 2015.

[7] D. J. Liska, C. M. Cook, D. D. Wang, and J. Szpylka, "Maillard reaction products and potatoes: have the benefits been clearly assessed", Food Science and Nutrition, Wiley Periodicals Inc, 2015.

[8] M. Romadhoni, and Harijono, "Pasting properties of lesser yam flour, sago starch and carrageenan and its potential for vermicelli", Agro-Industry and Food Journal, Vol. 3, No. 1, pp. 53-60, 2015.

[9] K. Patil, "Health benefits of food: organic facts", Organic Information Services Pvt Ltd, 2015.
[10] S. S. Yuwono, and A. A. Zulfiah, "Formulation of analogue rice base mocaf and maizena flour with addition cmc and tofu waste flour", Agro-Industry and Food Journal, Vol. 3, No. 4, pp. 1465-1472, 2015.

[11] C. Ruan, and J. Yang, "Hesitant fuzzy multi-attribute decision-making method considering the credibility", Journal of Computational Information Systems, Vol. 11, pp. 423-432, 2015.

[12] M. Jaberidoost, L. Olfat, A. Hosseini, A. Kebriaeezadah, M. Abdollahi, M. Alaeddini, and R. Dinarvand, "Pharmaceutical supply chain risk assessment in iran using analytical hierarchy process and simple additive weighting methods", Journal of Pharmaceutical Policy and Practice, pp. 8-9, 2015.

[13] R. N. P. Atmojo, "Simulation modelling of tablet pcs selection using weighted product algorithm", Applied Mathematical Sciences, Vol. 8, No. 115, pp. 5705-5719, 2014.

[14] B. Prihasto, M. I. Irawan, A. Masduqi, "Fuzzy madm method for decision support system based on artificial neural network to water quality assessment in surabaya river", Journal of Soft Computing and Decision Support Systems, Vol. 1, No. 1, pp. 24-29, 2014.

[15] M. Ahsan, P. B. Santoso, and H. S. Dachlan, "Multiple intelligence for determining field of study at sma using multi-attribute decision making”, EECCIS Journal, Vol. 9, No. 1, pp. 25-31, 2015.

[16] E. Sediyono, A. Setiawan, D. R. Kaparang, "Fuzzy simple additive weighting algorithm to determine land suitability for crop in minahasa tenggara", International Journal of Computer Applications, Vol. 84, No. 7, pp. 26-29, 2013.

[17] H. Ismanto and Azhari, "Multi attribute decision making method for determination of regional development plan priority in papua province based on the indicator of gross regional domestic product", International Journal of Computer Applications, Vol. 117, No. 7, pp. 21-26, 2015.

[18] R. N. P. Atmojo, "Simulation modelling of tablet pcs selection using weighted product algorithm", Applied Mathematical Sciences, Vol. 8, No. 115, pp. 5705-5719, 2014.

[19] L. Abdullah and C.W. R. Adawiyah, "simple additive weighting methods of multi criteria decision making and applications: a decade review", International Journal of Information Processing and Management, Vol. 5, No. 1, pp. 39-49, 2014.

[20] K. S. S. Anupama, S. S. Gowri, B. P. Rao, and P. Rajesh, "Application of madm algorithms to network selection", International Journal of Innovative Research in Electrical, Electronics, Instrumentation and Control Engineering, Vol 3, Issue 6, pp. 64-67, 2015.

\section{Authors' Profiles}

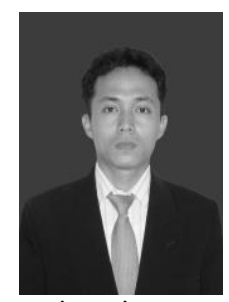

Adriyendi, he received the Master's degree in computer science from UPI YPTK Padang, in 2009. Currently, he is a lecturer at UPI YPTK Padang and STAIN Batusangkar, Indonesia. His research interests include decision support systems, image processing, healthcare informatics, artificial intelligent, food science, data mining, and information engineering. 